\title{
ARILHA, Margareth; RIDENII, Sandra G. Unbehaum; MEDRADO, Benedito (Org.). Homens e masculinidades: outras palavras. São Paulo: Ecos: Editora 34, 1998. $304 \mathrm{p}$.
}

\section{Márcia Thereza Couto* \\ Universidade Federal de Pernambuco - Brasil}

\section{Masculino...? Não, masculinidade!}

Circulando nos fóruns de debates teóricos na academia e/ou na prática dos movimentos reivindicatórios feminista e gay, sobretudo desde a década de 60, diferentes sujeitos vêm lançando-se na busca da desconstrução ou desnaturalização dos já arraigados atributos conferidos aos sexos ao mesmo tempo, em que apontam para a necessidade de entender os atos corporais, sexuais e reprodutivos como construções sociais, e não meramente pertencentes à esfera biológica. Assim, não é de hoje que ecoam vozes solicitando a entrada definitiva dos homens (como sujeitos e objetos de estudo) no campo das investigações de gênero.

Tributários no campo teórico e metodológico desta perspectiva, que constitui-se fortemente como comparativa, histórica e construtivista, os estudos sobre masculinidade começam a surgir nos países anglo-saxões já na década de 70. Entretanto, é ao longo da década de 80 que as pesquisas acerca da construção social da masculinidade começam a ganhar força internacionalmente, na medida em que a diversidade de temas é incorporada. No Brasil, a temática emerge no momento (décadas de 80 e 90) em que o entendimento de que não se pode mais falar de feminilidade e masculinidade no singular tem sido a tônica.

Doutoranda em Sociologia. 
Neste sentido, é oportuna e promissora a publicação do conjunto de textos que relatam pesquisas, projetos de intervenção ou mesmo experiências pessoais no trabalho com/entre homens organizada por Margareth Arilha, Sandra Ridenti e Benedito Medrado. Oportuna porque através das discussões realizadas pelos que fazem o Gesmap (Grupo de Estudos sobre Sexualidade Masculina e Paternidade) dentro da Ecos (Estudos de Comunicação e Sexualidade em Reprodução Humana), ONG sediada em São Paulo, resulta a proposta do livro, que é a de contribuir para a produção e divulgação do conhecimento e também para a reflexão e formulação de políticas públicas. Promissora, nesta época de intensa e ininterrupta reformulação dos paradigmas das Ciências Sociais e consolidação da categoria analítica gênero, quando mais e mais necessário se faz a consideração do princípio básico desta categoria: seu caráter relacional.

Esta que se constitui na primeira coletânea brasileira sobre homens e masculinidades, com enfoque especial no campo da sexualidade e reprodução, integra artigos de diferentes autores, sobre diferentes temas, mas com base numa mesma perspectiva: o caráter construtivista e relacional das identidades sexuais e das relações assimétricas entre os gêneros. No geral, oriundos de seus projetos e pesquisas acadêmicas (em mestrado ou doutorado) ou de seus trabalhos de intervenção na cidade de São Paulo, procuram refletir sobre alguns aspectos da experiência de "ser homem" em diferentes grupos sociais marcados por características particulares no campo etário, étnico e de classe. Apresenta-se estruturado em dois grandes blocos temáticos: "sexualidade e reprodução: dimensões do masculino" e "homens e cuidado infantil: permanências e rupturas” e, por fim, abre espaço a relatos de experiências pessoais de pesquisadores acerca de uma interessante dimensão ainda pouco explorada: o olhar de homens sobre homens (e "relacionalmente" mulheres) para quem trabalha na perspectiva de género.

O primeiro bloco tenta responder a questão: "está a sexualidade para o homem assim como a reprodução está para a mulher?”. ${ }^{1}$ Este, reúne trabalhos de Sandra Garcia, Margareth Arilha, Suzana Kalckmam, Elizabeth Pinto e Wilza Villela. Apesar de enfocar diferentes temas da saúde reprodutiva e sexual segundo repertórios masculinos, todas partem da constatação que a temática

1 Cf. Leal e Boff (1997). 
da reprodução estruturou-se com a ausência das masculinidades. Em outras palavras, que os estudos de gênero no país que focalizaram as dimensões masculinas, o fizeram a partir da sexualidade, sobretudo da homossexualidade.

Talvez por tratarem de aspectos polêmicos de um tema que nos últimos anos tem-se apresentado como prioritário nas agendas das agências internacionais financiadoras de pesquisa - a área dos direitos reprodutivos e o impacto do papel masculino na reprodução -, os textos deste bloco constituem, sem dúvida alguma, alguns dos mais interessantes. Começando pelo artigo de Sandra Garcia que discute os avanços do debate teórico dos estudos de gênero quando o foco é a questão das masculinidades, temos uma visão da produção inglesa e norte-americana sobre o tema, onde o gênero é visto como uma forma de estruturação das práticas sociais em geral, estando sua ordenação necessariamente vinculadas à raça, classe, etnia, entre outras. Assim, para entender como se estruturam masculinidade e feminilidade é necessário ir além do gênero, e para entender classe, raça, etc., deve-se mover em direção à dimensão género. Um outro trabalho interessante aqui é o de Suzana Kalckman. A partir de diversas experiências de investigação, discute a influência decisiva dos homens na determinação das formas como as mulheres conduzem sua saúde reprodutiva, destarte estes historicamente colocarem-se à margem das discussões sobre o tema, seja no âmbito privado ou público. Também, elabora questionamentos (indispensáveis) compartilhados por Wilza Villela acerca da necessidade de inclusão das populações masculinas em projetos de intervenção: como incorporá-las às propostas de atendimento à saúde? Como trazê-las para espaços onde, cada vez mais, predominam ações isoladas e curativas? Como congregar as particularidades destas populações masculinas a uma diretriz política no campo da saúde de caráter mais amplo?

O cuidado infantil, campo privilegiado da dinâmica familiar e da reprodução social, e histórica e culturalmente imputado à mulher, é analisado no segundo bloco da coletânea a partir não apenas das mudanças ocorridas na sociedade nas últimas décadas, e dos seus impactos do desempenho dos papéis familiares atribuídos aos homens (pai provedor) e às mulheres (mãe afetiva, protetora). Mas, sobretudo a partir da perspectiva de género onde também são refletidas as tradicionais concepções de masculinidade e feminilidade e onde busca-se desconstruir as arraigadas noções de que a maternagem está intimamente atrelada ao aspecto biológico, enquanto a paternagem define-se cultural 
e socialmente, aparecendo desvinculada do processo reprodutivo. Incluindo pela primeira vez estudos conduzidos por homens (Benedito Medrado e Jorge Lyra), ainda entre a maioria realizados por mulheres (Sandra Ridenti, Malvina Muskat e Elizabeth Cruz), temas díspares como repertórios sobre masculinidade e cuidado infantil veiculados pela mídia, paternidade adolescente, disputas parentais pela custódia dos filhos, violência de gênero e paternidade e as representações do masculino no contexto da creche são, respectivamente, abordados.

A literatura teórica, fortemente a norte-americana, referente a "nova paternidade” (que reflete um modelo de participação mais efetivo do pai no cotidiano familiar e, especialmente, no cuidado com a criança) permeia o conjunto dos trabalhos deste segundo bloco. Entretanto, sente-se falta de uma adequação desta literatura à conformação dos atributos de gênero da nossa sociedade e às particularidades dos arranjos familiares em diferentes grupos sociais. Esta necessidade torna-se clara nas propostas de intervenção apresentadas ou sugeridas em alguns artigos. Se, por um lado, entende-se que a compreensão das representações e práticas masculinas podem favorecer na melhoria dos resultados de programas voltados para a saúde das crianças, para a prevenção de DSTs e nas decisões de planejamento familiar, sem esquecer o aspecto da construção de relações mais simétricas entre os géneros, não se pode esquecer que as múltiplas formas de viver a masculinidade nos planos individual e familiar encontram-se conectadas a diferentes realidades sócio-culturais. Permanências e rupturas nos valores e comportamentos dos sujeitos na família devem ser analisadas dentro dos contextos que as geram.

O relato de experiências constitui uma peça fundamental nesta coletânea que aborda temas polémicos circunscritos a uma "nova” esfera de produção académica e de debate e reivindicações políticas. Os relatos apresentados por Sérgio Barbosa, Leandro Andrade e Reginaldo Bianco situam com precisão as dúvidas metodológicas, os conflitos éticos... enfim, a inquietude e esperança que perpassa as mentes daqueles que, mais do que um trabalho acadêmico, buscam contribuições à luta pelo respeito à pluralidade e diversidade, caminho para a igualdade e cidadania para todos.

É certo que as pesquisas recentes sobre masculinidades vêm seguindo a trilha inaugurada pelos estudos de gênero de enfoque feminista. Ao contrário destas, que num primeiro momento (dada a necessidade de descrever, discutir 
e denunciar a condição feminina) "excluíram” os homens, tomando-os muitas vezes como mero contraponto, as pesquisas sobre masculinidade iniciam-se num caminho já aberto e mais estruturado, especialmente com a afirmação teórica da categoria analítica gênero. Visibilidade, referência e possibilidade de financiamento para projetos de pesquisa e intervenção estão dadas. A coletânea vem estimular a reflexão e o diálogo entre aqueles que há muito estão ávidos pela entrada dos homens no debate de gênero. Mas, quem 1er Homens e Masculinidades não escapa ao questionamento: por que, mesmo numa das obras "inaugurais" no país sobre o universo das representações e práticas masculinas, ainda são os homens, enquanto questionadores/ investigadores, minoria?

\section{Referência}

LEAL, O. F.; BOFF, A. Insultos, queixas, sedução e sexualidade: fragmentos de identidade masculina em uma perspectiva relacional. In: PARKER, R.; BARBOSA, R. (Org.). Sexualidades brasileiras. Rio de Janeiro: Relume Dumará, 1997. 